\title{
KONCEPT ZERWANIE W DYSKURSIE ROSYJSKICH I ANGIELSKICH UŻYTKOWNIKÓW FORÓW
}

\author{
КОНЦЕПТ РАЗРЫВ ОТНОШЕНИЙ В ДИСКУРСЕ \\ РУССКИХ И АНГЛИЙСКИХ ФОРУМЧАН \\ THE CONCEPT OF A BREAK-UP \\ ON RUSSIAN AND ENGLISH LOVE FORUMS
}

\author{
Natalia Zatoń \\ Uniwersytet im Adama Mickiewicza w Poznaniu, Poznań - Polska
}

\begin{abstract}
The aim of this article is to present the concept of a break-up on Russian and English love forums. In the center of our interest was the question how the feelings and emotions are narrated and whether there are any noticeable gender or cultural differences. Computer Mediated Communication Discourse Analysis was used as a scientific method in this research. The results of the research show that there are several patterns of behavior which influence the discourse of forum users. Linguistic analysis of the discourse revealed differences between normal communication and computer mediated communication.

Słowa kluczowe: koncept, dyskurs, zerwanie, komunikacja za pomocą komputera, gender, forum

Ключевые слова: концепт, дискурс, разрыв отношений, коммуникация с помощью компьютера, гендер, форум

Keywords: concept, discourse, break-up, Computer Mediated Communication, gender, forum
\end{abstract}

Relacje międzyludzkie i powiązane $\mathrm{z}$ nimi przeżycia są podstawą badań specjalistów z różnych dziedzin. Temat miłości, zarówno szczęśliwej jak i nieszczęśliwej, od niepamiętnych czasów pojawia się w literaturze i szeroko pojętej sztuce; udowadnia to ważne miejsce tej sfery uczuciowej w życiu człowieka. Niebagatelną kwestią okazuje się rozpad związku dwojga ludzi, a przede wszystkim następujące po nim reakcje psychiczne oraz emocjonalne. Zerwanie kojarzone jest $\mathrm{z}$ wachlarzem negatywnych następstw: depresją, lękiem, poczuciem samotności, tłumieniem uczuć czy też alienacją i obawą przed ponownym zaangażowaniem ${ }^{1}$. Ze względu na ogrom emocji towarzyszących rozpadowi związku

${ }^{1}$ D. Davis, P. R. Shaver, M. L. Vernon, Physical, emotional, and behavioral reactions to breaking up: The roles of gender age, emotional involvement, and attachment style, "Personality and Social Pychology Bulletin" 2003, no. 29, [w:] źródło elektroniczne: http://psp.sagepub.com/cgi/ content/abstract/29/7/871 (21.12.2013), s. 871-884. 
dwojga ludzi wiele prac poświęca się analizie samego zjawiska zerwania, jego skutków i wpływu na emocje i dalsze życie uczuciowe obu stron.

W centrum zainteresowania badaczy pojawiają się różnice genderowe oraz kulturowe, zwraca się uwagę na to w jakiej formie mówi się o uczuciach i jakie środki wyrazu są w tym celu stosowane. Rozwój nowych technologii, oraz pojawienie się platform należących do grona serwisów określanych Web 2.0, skierowało uwagę badaczy także na zagadnienia związane z komunikacją za pomocą komputera (CMC - Computer Mediated Communication²). Serwisy należące do Web 2.0 charakteryzują się bardzo dużym wkładem ze strony samych użytkowników, a nie tylko twórców. Platformy te opierają się na treściach i materiałach zamieszczanych przez internautów oraz na interakcjach zainspirowanych w odpowiedzi na multimedialną zawartość danych stron. Przykładami takich serwisów mogą być Facebook, Gmail, Youtube, Google Docs, Sound Cloud, Google Wave, Prezi. W ramach analizy dyskursu użytkowników różnych serwisów bierze się pod uwagę strukturę wypowiedzi, znaczenie, rodzaj interakcji oraz aspekty socjolingwistyczne ${ }^{3}$.

We współczesnych badaniach dotyczących komunikacji za pomocą komputera zwraca się dużą uwagę na możliwości, jakie otworzył przed swoimi użytkownikami internet i platformy Web 2.0. Podkreśla się kwestię dużej anonimowości internautów oraz asynchroniczność komunikacji na niektórych serwisach jako aspekty wpływające na sposób i rodzaj prowadzonej wymiany informacji. Nie sposób nie wspomnieć o kwestii równości, szczególnie jeśli chodzi o kwestie genderowe. Jako przykład badania łączącego analizę dyskursu w komunikacji za pomocą komputera $\mathrm{z}$ aspektami genderowymi i kulturowymi można przytoczyć artykuł Antonio Garcia Gomeza traktujący o odcieleśnieniu i przestrzeni cyfrowej, a w szczególności o dyskursie genderowym w narracji nastolatek $^{4}$. Pod uwagę bierze się wypowiedzi dotyczące związków na brytyskich oraz hiszpańskich blogach. Badacz podkreśla, iż analiza wpisów odkrywa nowy kontekst $w$ ramach tego jak młode osoby kreują swoją

2 J. Grzenia, Komunikacja językowa w Internecie, Warszawa 2006, s 13-43. Zob. także: S. Herring, Computer-mediated discourse analysis: An approach to researching online behavior, [w:] S. A. Barar, R. Kling and J. H. Gray (eds), Designing for Virtual Communities in the Service of Learning. New York-Cambridge: Cambridge University Press 2004, [w:] źródło elektroniczne: http://ella.slis.indiana.edu/ herring/cmda.pdf (01.11.2013).

${ }^{3}$ S. Herring, Discourse in Web 2.0: Familiar, reconfigured, and emergent, [w:] D. Tannen \& A. M. Tester (eds.), Georgetown University Round Table on Languages and Linguistics 2011: Discourse 2.0: Language and new media, Washington, DC: Georgetown Univ. Press, s. 1-25, [w:] źródło elektroniczne: http://ella.slis.indiana.edu/ herring/GURT.2011.prepub.pdf (29.12.2013).

${ }^{4}$ A. G. Gomez, Disembodiment and cyberspace: Gendered discourses in female teenagers' personal information disclosure, “Discourse Society" 2010, no. 21, s. 135-160. 
tożsamość, także w odniesieniu do swoich byłych i obecnych partnerów. Gomez sugeruje, że społecznie postrzegana tożsamość nastolatków nie pokrywa się z tożsamością, którą oni sami chcą kreować i rozwijać. Internet daje użytkownikom wybór tego w jaki sposób będą wyrażać $\mathrm{w}$ dyskursie siebie i swoje role genderowe ${ }^{5}$.

Platformy należące do Web 2.0 okazują się być wykorzystywane niejednokrotnie jako źródło wiedzy i wsparcia emocjonalnego. Osoby, które przeżyły rozstanie nie są tu wyjątkiem. Dyskusje toczące się na forach internetowych oraz portalach społecznościowych ujawniają wielką potrzebę użytkowników do rozmawiania na temat zakończonych związków a także emocji z tym związanych. W niniejszym artykule przedstawiam próbę analizy 2 forów - rosyjskiego (www.pickup.ru) oraz angielskiego (www.enotalone.com) pod względem możliwych różnic genderowych oraz kulturowych przejawiających się $\mathrm{w}$ dyskursie dotyczącym aspektu zerwania i jego konsekwencji. Celem badania było określenie czy występują różnice między dyskursem kobiet i mężczyzn w odniesieniu do zakończonej relacji. Kontrastowo zostały pokazane tendencje występujące na forum angielskim i rosyjskim, z założeniem iż dyskurs może zależeć od podłoża kulturowego. Podstawowym założeniem badań było stwierdzenie iż przedstawiciele różnych płci, oraz różnych sfer kulturowych w odmienny sposób będą się wypowiadać na temat zerwania w komunikacji za pomocą komputera. Wzięte pod uwagę zostały przesłanki z gruntu psychologicznego, w tym także niektóre stereotypy.

Obydwa fora zostały wybrane ze względu na zbliżony profil i podobny zakres poruszanych tematów. Są to grupy dyskusyjne potocznie określane mianem stron dla zakochanych, gdzie temat zerwania jest wyodrębniony jako samodzielna kategoria wpisów. Do analizy zostało wybrane 60 wpisów, po 30 z każdego forum. Głównymi kryteriami wyboru były: zgodność tematu (zerwanie jako punkt wyjściowy), jak największa aktualność (nie starsze niż sprzed 6 miesięcy), zbliżona struktura (zgodna $\mathrm{z}$ wymogami administratorów forów) oraz wiek użytkowników (mieszczący się w zakresie 18-29 lat). Początkowe założenie o zachowaniu równej proporcji między wpisami kobiet i mężczyzn zostało odrzucone ze względu na dużą dysproporcję aktywności przedstawicieli obu płci na forach. Analiza wpisów została oparta o model analizy dyskursu komunikacji za pomocą komputera (CMDA - Computer Mediated Discourse Analysis) 6 .

Jednym z założeń CMDA jest fakt, iż dyskurs odzwierciedla pewne powtarzające się wzorce (stosowane $\mathrm{w}$ wypowiedzi świadomie lub nieświadomie). Jednocześnie ukazuje wybory dokonane przez wypowia-

${ }^{5}$ Ibidem, s. 136-137.

${ }^{6}$ S. Herring, op. cit., [w:] źródło elektroniczne: http://ella.slis.indiana.edu/ herring/ cmda.pdf (29.12.2013). 
dającego się, zarówno te lingwistyczne, jak i kognitywne i socjalne7. Zgodnie z tymi założeniami najpierw, na każdym z forów wyodrębnione zostały makrotematy - tematy przewodnie, które pojawiały się $\mathrm{w}$ największej liczbie wpisów, określone zostały tendencje i powtarzające się schematy. Następnie analizie zostały poddane cechy lingwistyczne i ekstralingwistyczne wybranych wypowiedzi. Procedura wyodrębniania makrotematów na każdym $\mathrm{z}$ forum przebiegała $\mathrm{w}$ taki sam sposób. Głównym celem było znalezienie wspólnych tendencji i schematów powtarzających się $\mathrm{w}$ wielu wpisach dotyczących samego faktu zerwania oraz konsekwencji tego zjawiska. W centrum zainteresowania były także środki lingwistyczne używane do wyrażenia uczuć i emocji. Nazwy makrotematów są określeniami utworzonymi przeze mnie jedynie na potrzeby tego badania. Literatura $\mathrm{z}$ dziedziny psychologii, traktująca o zerwaniu i jego konsekwencjach, została uwzględniona $\mathrm{w}$ procedurze dopiero po przeprowadzeniu analizy tematycznej, aby treści tam zawarte nie wpłynęły na ocenę materiału. Po zakończeniu wyodrębniania grup wpisów mających wspólne schematy i udowadniających pewne tendencje, porównano zebrany materiał z literaturą specjalistyczną. Zauważono zgodność pewnej części wyników z konceptami opisywanymi $\mathrm{w}$ literaturze psychologicznej. Poniżej zaprezentowano wyodrębnione makrotematy, a następnie przedstawiono je $\mathrm{w}$ kontraście $\mathrm{z}$ informacjami zaczerpniętymi ze wspomnianej literatury. Przykłady wypowiedzi zostały przytoczone $\mathrm{w}$ oryginalnej formie, nie ingerowano $\mathrm{w}$ gramatykę, ortografię ani interpunkcję. Tłumaczenia są mojego autorstwa.

W obrębie forum angielskiego zostało wyodrębnionych 7 makrotematów: 1. „no contact” (brak kontaktu) jako najlepsze lekarstwo, 2. poczucie niesprawiedliwości / złość w stosunku do ekspartnera / ekspartnerki, 3. nieustająca miłość, 4 . obawa przed ponownym zakochaniem się, 5 . bezradność wobec ogromu emocji / prośba o pomoc, 6. ciągłe zmiany emocjonalne oraz 7. radzenie sobie z wiadomościami od ekspartnera/ekspartnerki. Najważniejszą cechą łączącą wszystkie makrotematy było silne nacechowanie emocjonalne wypowiedzi forumowiczów. Przeważająca część wpisów ujawniała negatywne następstwa zerwania: samotność, narastający gniew, trudny do opanowania natłok emocji oraz niepewność w kwestii przyszłości (What Id do just to rewind 2 years to be happy again, this has been the worst year of my life, I pray everynight things will get better but I know deep down they aren't - To co chciatbym zrobic to cofnać te 2 lata, znowu być szczęśliwym. To był najgorszy rok w moim życiu, modle sie codziennie żeby byto lepiej, ale w głębi duszy wiem, że to się nie stanie). Poza makrotematem "nieustająca miłość" ekspartnerzy/rki przedstawiani są jako przyczyna cierpienia i problemów, forumowicze wyrażają swój

7 Ibidem. 
ogromny żal i pretensje, obarczając stronę przeciwną odpowiedzialnością za zerwanie i jego negatywne konsekwencje. W obrębie makrotematów „,brak kontaktu jako najlepsze lekarstwo”, ,"bezradność wobec ogromu emocji” i "ciągłe zmiany emocjonalne" z łatwością można zaobserwować strategie oraz schematy opisywane jako najczęściej pojawiające się $\mathrm{W}$ odpowiedzi na zerwanie relacji dwojga ludzi. Przede wszystkim występuje taktyka unikania, dążenie do całkowitego wyeliminowania $\mathrm{z}$ rzeczywistości wszystkiego co jest $\mathrm{w}$ jakikolwiek sposób powiązane $\mathrm{z}$ ekspartnerem / $\mathrm{kac}$ (I finally got really pissed a week ago and told him not to contact me ... and I told him he can't go in and out of my life. I've eliminated him from all my social networks/deleted his number etc. - W końcu naprawde się zezłościłam i powiedziałam mu, żeby się ze mna nie kontaktowat... i powiedziałam mu że nie może pojawiać się i znikać z mojego życia. Usunęłam go ze wszystkich serwisów / usunęłam jego numer itd.). Osoby skłaniające się ku takiemu rozwiązaniu trzymają swoje emocje na wodzy, nie szukają potwierdzenia swoich racji $u$ innych, polegają na swojej ocenie sytuacji. Mogą wykazywać skłonności do używania alkoholu lub różnych substancji odurzających ${ }^{8}$.

Makrotematy „poczucie niesprawiedliwości/złość w stosunku do ekspartnera/ekspartnerki” oraz „nieustająca miłość” obrazują pierwszą fazę reakcji na zerwanie - fazę protestu. Na tym etapie emocje są najsilniejsze, występuje też niedowierzanie temu co się zdarzyło, są podejmowane usilne próby odzyskania utraconych relacji miłosnych (Please $i$ really miss her and think of her everyday! - Prosze ja naprawde za nia tęsknie i myślę o niej codziennie!). „Bezradność wobec ogromu emocji” oraz „ciągłe zmiany emocjonalne" obejmują wpisy charakteryzujące fazę rozpaczy. $\mathrm{W}$ jej trakcie następuje przyjęcie do wiadomości rozpadu związku i faktu, że były partner został utracony. Faza rozpaczy często charakteryzuje się występowaniem problemów z jedzeniem i spaniem, nastrojami depresyjnymi, wycofaniem z życia społecznego, oraz przemożnym smutkiem (But it's been SO hard for me---I'm an emotional rollercoaster and completely heartbroken. --- every morning I wake up---sad, depressed, thinking about him. - Ale to byto TAK trudne dla mnie-jestem na huśtawce emocjonalnej i mam złamane serce - każdego ranka budze się---smutna, w depresji; myślac o nim). Stopień intensywności reakcji zależy od wielu czynników indywidualnych, takich jak poziom zażyłości między byłymi partnerami, osobiste zaangażowanie $w$ dany związek czy ogólna emocjonalność jednostki ${ }^{9}$. Zupełnie odmiennym etapem jest tzw. reorganizacja, następująca po jednej lub po obu wyżej wymienionych fazach. Charakterystyczne dla

${ }^{8}$ D. Davis, P. R. Shaver, M. L. Vernon, op. cit, [w:] źródło elektroniczne: http://psp.sagepub. com/cgi/content/abstract/29/7/871, (21.12.2013), s. 873

${ }^{9}$ Ibidem. 
procesu reorganizacji jest zaangażowanie $\mathrm{w}$ nowe aktywności, lub powrót do dotychczasowych zainteresowań z właściwym dla danej osoby zaangażowaniem i energią. $W$ zależności od cech indywidualnych niektóre osoby mogą dojść do wniosku, iż zakończona relacja z daną osobą wzbogaciła ich doświadczenie życiowe, więc zachowanie przyjacielskich stosunków z dotychczasowym partnerem jest jak najbardziej możliwe ${ }^{10}$. Wpisy przyporządkowane do makrotematów "obawa przed ponownym zakochaniem się" oraz „radzenie sobie z wiadomościami od ekspartne$\mathrm{ra} / \mathrm{ki}^{\prime \prime}$ wskazują na długotrwały wpływ zerwania na działania i emocje jednostki. Nawet po przejściu początkowych faz, tj. protestu czy też desperacji, fakt zerwania może decydować o późniejszym postrzeganiu siebie oraz innych, radykalnym spadku samooceny oraz zaufania w stosunku do potencjalnych przyszłych partnerów/rek (At the moment it seems incomprehensible to me that I could have those feelings about someone new. I'm prepared for a long wait before the right person comes along, but reading others responses here makes me feel that that is at least normal - Na razie jest to dla mnie niewyobrażalne, że mógłbym żywić uczucia w stosunku do kogoś innego. Jestem przygotowany na dtugie czekanie na tę właściwa osobę, ale czytanie innych wpisów sprawia, że czuje, że to przynajmniej normalne).

Analiza wpisów na forum angielskim ukazała zdecydowane różnice w narracji kobiet i mężczyzn. Wpisy przedstawicielek płci pięknej były wyraźnie przepełnione negatywnymi emocjami, przede wszystkim gniewem i złością wobec ekspartnerów (My life is crashing down and I can't live being this low anymore. Iv sick everyday, I have to live with anxiety problems, - Moje życie runęło w gruzach i nie moge już tak żyć. Jestem chora każdego dnia, musze przezwyciężać problem jakim jest strach). Zakończony związek opisywany jest jako źródło bólu i cierpienia, dlatego też kobiety za wszelką cenę chcą unikać kontaktu z byłym. Wpisy kobiet potwierdzają tendencje do zmian emocjonalnych, nad którymi trudno jest zapanować, dlatego też wiele użytkowniczek usilnie prosi o pomoc w podjęciu decyzji. Uwidacznia się potrzeba znalezienia oparcia wśród innych osób na forum, otrzymania porad, aprobaty dla swoich decyzji i działań. Wpisy mężczyzn także charakteryzowały się wysokim stopniem emocjonalności, jednak wyrażane obawy i wątpliwości dotyczyły nie tyle chwili obecnej, ile kwestii przyszłościowych (I'm just really bothered by the feeling that nothing will ever compare to my first love - Naprawde sie martwie [moim] poczuciem, że nic nie będzie się mogło równać $z$ moją pierwsza miłościa). Zerwanie spowodowało, iż przedstawiciele płci męskiej utracili pewność siebie i wiarę $\mathrm{w}$ możliwość udanego życia emocjonalno-uczuciowego w przyszłości. W przeciwieństwie do kobiet, mężczyźni wydają się mieć większe problemy z odcięciem się od byłej partnerki, wciąż ży-

${ }^{10}$ Ibidem, s. 874. 
wią wobec niej pozytywne uczucia. Decyzja o braku kontaktu jest trudniejsza do podjęcia, przynosi więcej cierpienia, a okres powrotu do stanu emocjonalnego sprzed zakończonego związku jest dłuższy niż można wnioskować z wpisów kobiet.

W kwestii językowej na forum angielskim można zaobserwować nagminne użycie akronimów takich jak NC (no contact - brak kontaktu), OW (other woman - inna kobieta), BU (breakin-up - zerwanie) oraz wielu innych. Skróty te nie są charakterystyczne dla analizowanego forum, powszechnie występują na różnych serwisach anglojęzycznych. Funkcją owych skrótów jest przyspieszenie i usprawnienie komunikacji, używanie ich stwarza wrażenie przynależności do danej grupy, społeczności, która wypracowała pewien system komunikacji. Komunikacja za pomocą komputera wymusza pewne zmiany w użyciu zarówno gramatyki jak i ortografii, głównie ze względu na niemożliwość użycia odpowiednich gestów, dźwięków i mimiki. Specyficzna typografia i ortografia $z$ reguły mają za zadanie odzwierciedlić zamierzone emocje i podteksty wypowiedzi. Poziom i częstotliwość użycia różnych zabiegów w komunikacji za pomocą komputera są zależne od języka, w którym odbywa się komunikacja, od specyfiki używanego urządzenia, charakteru danego serwisu lub cech indywidualnych jego użytkowników ${ }^{11}$. Na forum angielskim najczęściej spotykane zabiegi to użycie wielokropków (np. which is always really tough for me...; Ex wants to talk... - to jest zawsze bardzo trudne dla mnie...; była chce porozmawiać...), emotikon (I used to be sooo happy with her........... : - bytem tak szczęsliwy $z$ niq......... :) $)$, wielokrotnych wykrzykników (since then I've been at a loss!!; I go out a lot, made lots of new friends!! - od tego czasu jestem stracony!!; dużo wychodzę, poznałem wielu nowych znajomych!!) oraz niestandardowej kapitalizacji (I am still REALLY struggling; I COULD love in the future; But it's been SO hard for me - Ja NAPRAWDĘ wciaż walczę; MÓGŁBYM kochać w przyszłości; ale to była TAK trudne dla mnie). Wszystkie wymienione zabiegi są określane jako standardowe dla komunikacji za pomocą komputera ${ }^{12}$. Badany materiał sugeruje iż wielokropki z reguły mają odzwierciedlać pauzy w wypowiedzi, niepewność, zawahanie lub melancholię osoby wypowiadającej się. Emotikony, wykrzykniki i niestandardowa kapitalizacja mają różnorakie zastosowanie. Przede wszystkim mają obrazować silne emocje, podkreślać najważniejsze części wypowiedzi, dawać upust złości i niezadowoleniu. Brak odpowiedniej kapitalizacji może być wynikiem zwykłej niedbałości o formę wypowiedzi.

${ }^{11}$ S. C. Herring, Grammar and Electronic Communication, [w:] C. Chapelle (ed.) Encyclopedia of applied linguistics, Wiley-Blackwell 2011.

12 Ibidem. 
Analiza forum rosyjskiego pozwoliła wyodrębnić następujące makrotematy: 1. cierpienie i rozpacz, 2. idealizacja ukochanej/ukochanego, 3. samodoskonalenie, 4. nieprzeparte uczucie własnej głupoty. Przyporządkowanie owych makrotematów do omawianych już faz występujących po zerwaniu relacji okazało się dużo trudniejsze niż na forum angielskim. Wiele wpisów łączy w sobie cechy charakterystyczne dwóch lub trzech faz, granice między poszczególnymi etapami albo się rozmywają, albo w ogóle nie są widoczne. W obrębie makrotematu „cierpienie i rozpacz" występują wpisy najbardziej emocjonalne, przepełnione złością, poczuciem niesprawiedliwości, skrzywdzenia, żalu, zagubienia w rzeczywistości. Forumowicze usilnie domagają się rad i pomocy, tłumaczą się ze swoich decyzji i działań, wspólnie szukają nowych rozwiązań (Как мне поступить? Как мне действовать? Помогите мне, вариант забыть и искать другого мучше не предлагайте, сама об этом думала). "Idealizacja ukochanej / ukochanego" to makrotemat obejmujący wpisy pełne pozytywnych ocen byłych partnerów i partnerek. Użytkownicy nawet jeśli czują się skrzywdzeni zaistniałą sytuacją to nie ukrywają swojego zachwytu zaletami drugiej osoby, podkreślają jej wyjątkowość, byliby w stanie wiele wybaczyć jeśli tylko byłaby możliwość powrotu do zakończonej relacji (Она - мисс популярность, лучезарная такая, красивая, из тех о ком много сплетничают, но мало что знают). Trzeсі makrotemat, "samodoskonalenie”, dotyczy jedynie mężczyzn. Znacząca ilość wpisów poświęcona była działaniom podjętym po zerwaniu $\mathrm{w}$ ramach reorganizacji swojego życia. Mężczyźni dzielili się na dwie grupy. Jedna $\mathrm{z}$ nich podjęła decyzję o samodoskonaleniu $\mathrm{w}$ ramach planu odzyskania utraconej partnerki. Wyszli oni z założenia, że spełnienie pewnych oczekiwań swoich ekspartnerek, może zmienić decyzję kobiet dotyczącą zerwania. Druga grupa mężczyzn postanowiła zmienić swoje życie w jakimś aspekcie, aby podnieść własną samoocenę i stać się atrakcyjnymi dla przyszłych partnerek (РазВиВаю себя. Курсы английского + пойду в тренажерку на днях. Музыка. Меняю стиль. Читаю книги по пикапу). Ich zamiarem było udowodnienie sobie i innym, że w przeszłości ich nie doceniono. Samodoskonalenie obejmowało różne sfery - poprawę kondycji fizycznej, rozwój intelektualny, zmianę wyglądu, zainteresowań czy też stylu życia. Ostatni makrotemat „nieprzeparte uczucie własnej głupoty" ukazuje zerwanie jako największą pomyłkę w życiu forumowiczów. Widoczne są tutaj wszystkie fazy opisywane wcześniej. Najczęściej wpisy pełne są rozczarowania własnymi, nieudolnymi działaniami, pomyłkami i pochopnymi decyzjami. Są to wypowiedzi zdecydowane, nie pozostawiające wiele miejsca na domysły (Короче ребята, я идиот. [...] Пожалуйста помогите убогому. Хоть как-то).

Analiza wpisów pod względem genderowym pokazuje, że kobiety są bardziej emocjonalne w swojej narracji, a ich opisy są bardziej metafo- 
ryczne (В итоге он сел мне на шею. Грубо говоря ноги лизала. По его словам вечно не права я... Вечно пытается „выити чистым из воды”). Żeńska część forumowiczów nie jest skłonna do oceniania swoich ekspartnerów, występuje raczej potrzeba uzyskania wsparcia i rad. Cała uwaga skupia się na ich osobie, ich przeżyciach i przemyśleniach. Narracja męskiej części użytkowników jest bardzo szczegółowa i w każdym przypadku odpowiada wymaganiom administratorów ${ }^{13}$. Duży nacisk kładzie się na kwestię samodoskonalenia, poszukiwanie przyczyn problemów w sobie samym. Mężczyźni, w przeciwieństwie do kobiet, poszukują raczej poparcia dla podjętych już decyzji, a nie odpowiedzi na swoje pytania i wątpliwości; są zdecydowani i bardzo konkretni (Ситуация такова - встречался с девушкой 2,5 месяциа, знакомы были давно с одного мероприятия но не общались. Она где то 7-8 правильная умная девочка).

Podobnie jak na forum angielskim, na rosyjskim pojawia się ogromna ilość skrótów, które są powszechne dla forów tego rodzaju. Są to na przykład skróty ожп (особа женского пола - osoba płci żeńskiej), пз (признаки заинтересованности - oznaki zainteresowania) дод (давай останемся друзьями - zostańmy przyjaciółmi), т10д (тряхни 10 других - zalicz 10 innych) itp. Podobne jest również użycie wielokropków oraz wielokrotnych wykrzykników (все ему прощала... прекращаю наши отночения на время...; Помогите пожалуйста вернуть парня!!!!), które pełnią praktycznie takie same funkcje jak na forum angielskim. Nie występuje niestandardowa kapitalizacja, jedynie niektóre wpisy pozbawione są znaków interpunkcyjnych. Użycie emotikon jest bardzo znikome.

Analiza obu forów ukazuje pewne pozalingwistyczne różnice między wpisami. Warto zwrócić uwagę, że mężczyźni są dużo bardziej aktywni na forum rosyjskim, na którym to wyróżnia się makrotemat stworzony jedynie przez przedstawicieli tej płci. Dużo więcej panów na forum rosyjskim jest skłonnych walczyć o byłą partnerkę, podczas gdy na angielskim więcej osób skłania się ku stosowaniu zasady no contact (brak kontaktu). Wpisy na forum rosyjskim są bogatsze $\mathrm{w}$ pozytywne emocje, użytkownicy idealizują byłych partnerów, piszą o pozytywnych uczuciach, o procesie samodoskonalenia i planach na przyszłość. Wpisy na forum angielskim przepełnione są negatywnymi emocjami, nawet agresją. Nie udało się wyodrębnić żadnego pozytywnego makrotematu. Materiał zebrany z obu forów sugeruje wielką potrzebę internautów do uzyskania pomocy i rady z zewnątrz, a także anonimowego wyrzucenia z siebie najróżniejszych emocji i przemyśleń.

\footnotetext{
${ }^{13} \mathrm{Na}$ forum obowiązuje schemat dotyczący tworzenia nowego wątku dotyczącego związku. Należy opisać partnera partnerkę, ocenić wygląd i charakter w skali od 1 do 10, przedstawić historię związku, a dopiero później opisać bieżący problem.
} 
Przedstawiona analiza rzuca nowe światło na niektóre założenia dotyczące tego jak kobiety i mężczyźni radzą sobie z emocjonalnymi przejściami, takimi jak na przykład zerwanie. We współczesnych badaniach emocji coraz większy nacisk kładzie się na to jak płeć jest połączona z odczuwaniem, przekazywaniem i wyrażaniem emocji. Psychologowie często odwołują się do stereotypów i powszechnych przekonań na temat przeżyć i związanych z nimi uczuć, badając na ile są one zgodne $\mathrm{z}$ prawdziwym wpływem różnych odczuć na nasze życie ${ }^{14}$. Jedną z najlepiej udokumentowanych reguł dotyczących różnic między kobietami i mężczyznami w kwestii wyrażania emocji jest fakt, iż mężczyźni jeśli nie są do tego nakłaniani, nie są skłonni do rozmów na tematy związków i relacji międzyludzkich. Są też zdecydowanie mniej zainteresowani rozmowami o emocjach powiązanych $\mathrm{z}$ owymi relacjami. W standardowej komunikacji niechęć ta zmniejsza się jeśli dyskusja toczy się w gronie samych mężczyzn, pozostających w bliskich relacjach przyjacielskich. Kobiety wykazują gotowość do dyskusji na temat emocji w dużo bardziej zróżnicowanym gronie ${ }^{15}$. Ważne jest też to, że mężczyźni uważają proszenie o pomoc i konsultacje u specjalisty za zachowanie bardzo niemęskie ${ }^{16}$.

Co więcej, nawet uczucia takie jak gniew, stereotypowo kojarzone z dyskursem mężczyzn, częściej są omawiane i analizowane w wypowiedziach kobiet. Wiele badań udowadnia, że kobiety od dzieciństwa są skłonne do okazywania oraz werbalnego wyrażania swoich emocji17.

Jeśli przyrównać tendencje omawiane $\mathrm{w}$ literaturze specjalistycznej do wyników przeprowadzonego badania można zauważyć pewne zależności. Trzeba podkreślić, że niechęć mężczyzn do uzyskiwania porad u specjalisty nie wpływa na stopień partycypacji na anonimowym forum internetowym. Można wysnuć wniosek iż taki sposób omawiania problemów i emocji (kwestia wspomnianego odcieleśnienia występującego w trakcie komunikacji za pomocą komputera) jest dla przedstawicieli tej płci bardzo komfortowy i nie krępujący. W odniesieniu do kobiet warto zauważyć, iż żadne reakcje emocjonalne - ani tłumienie gniewu, ani jego wybuchy nie były na forum krytykowane. Obie tendencje wy-

${ }^{14} \mathrm{~S}$. A. Shields, Thinking about gender, thinking about theory: Gender and emotional experience, [w:] A. H. Fisher, Gender and emotion: Social psychological perspectives, Cambridge 2000, s. 4.

${ }^{15}$ Ibidem, s. 3-8.

${ }^{16}$ R. O'Brien, K. Hunt, G. Hart, It's caveman stuff, but is to a certain extent how guys still operate: men's accounts of masculinity and help seeking, "Social Science \& Medicine" 2005, no. 61, [w:] źródło elektroniczne: http://www.academia.edu/336336/Its_Caveman_Stuff_but_That_is_ to_a_Certain_Extent_How_Guys_Still_Operate_Mens_Accounts_of_Masculinity_and_Help_S eeking, (12.12.2013), s. 503-516.

17 S. A. Shields, op. cit., s. 11. 
stępujące $\mathrm{w}$ codziennej komunikacji nie zostały potwierdzone $\mathrm{w}$ analizowanym materiale z zakresu komunikacji za pomocą komputera.

Zakończenie związku między ludźmi jest katalizatorem różnych sytuacji. W wielu sferach życia udaje się zaobserwować wpływ tego zjawiska na zachowanie działania różnych osób. Z przeprowadzonego badania wynika, iż pomimo dużej zależności postępowania byłych partnerów od ich cech indywidualnych, można wyodrębnić wspólne tendencje i schematy działań. Podobne są również środki lingwistyczne używane do wyrażania określonych emocji i uczuć. Analizowany materiał ukazał, że nie wszystkie stereotypowe założenia dotyczące życia emocjonalnego kobiet i mężczyzn są prawdziwe i uniwersalne. Znaczące różnice wskazano między tendencjami pojawiającymi się w zwykłej komunikacji i komunikacji za pomocą komputera. Przeprowadzone badanie może służyć jako baza dla dalszej analizy zarówno komunikacji za pomocą komputera $\mathrm{w}$ kontekście stereotypowego postrzegania kobiet i mężczyzn, a także w kontekście środków językowych używanych do narracji nasyconej emocjonalnie. 